\title{
Combining experimental auctions with a modified home-use test to assess rural consumers' acceptance of quality protein maize, a biofortified crop
}

\section{Paper accepted for publication in Food Quality and Preferences}

\author{
April 18, 2014
}
Hugo De Groote ${ }^{1 *}$, Christine Kiria Chege ${ }^{2}$, Keith Tomlins ${ }^{3}$, and Nilupa S. Gunaratna ${ }^{4}$

${ }^{1}$ International Maize and Wheat Improvement Centre (CIMMYT), PO Box 2041-00621

Nairobi; h.degroote@cgiar.org

${ }^{2}$ University of Pretoria; Department of Agricultural Economics, Extension and Rural Development, Private bag X20 Hatfield, Pretoria 0026, South Africa (currently at Georg-AugustUniversity of Goettingen, Germany); xtinahg@yahoo.com

${ }^{3}$ Natural Resources Institute, University of Greenwich, Greenwich, Medway Campus, Central Avenue, Chatham Maritime ME4 4TB, United Kingdom; K.I.Tomlins@greenwich.ac.uk

${ }^{4}$ Harvard School of Public Health, 677 Huntington Avenue, Boston, MA 02115USA; ngunarat@hsph.harvard.edu

* Corresponding author. Tel.: +254 20 7224600; fax: +254 20 7224601. E-mail address: h.degroote@cgiar.org (H. De Groote). 


\begin{abstract}
Biofortification, or breeding food crops for improved nutritional content, is a cost effective way to improve nutritional status. The process can, however, alter the sensory characteristics of the crop, and consumer acceptance is essential for their adoption. The oldest biofortified crop is quality protein maize (QPM), biofortified with essential amino acids, now found in many recently-released varieties in East Africa. To estimate rural consumers' acceptance and willingness to pay (WTP) for QPM in the dispersed population of Northern Tanzania, a novel method, combining a modified home-use test with a Becker-DeGroot-Marschak experiment, was developed. The results showed that rural consumers in Tanzania could distinguish stiff porridge made from QPM and from conventional maize $(\mathrm{CM})$. They generally preferred the former, as expressed by higher scores during affective tests for texture, taste, and overall qualities. Further, rural consumers who were not provided with information about the nutritional benefits of QPM were willing to pay a premium of $16 \%$ over CM, and those who were given information, $39 \%$. The scores on the affective test and the information on QPM's nutritional benefits were the main factors determining WTP in the experiment, while no personal characteristics of the participants were found to be significant. We conclude that QPM is, at least, as well accepted as conventional maize, and preferred for its sensory characteristics. Information on nutritional benefits increases rural consumers' willingness to pay for it, so information campaigns may be effective in increasing demand for QPM varieties. However, these varieties need to be competitive for other characteristics that rural households value, in particular, field and storage qualities.
\end{abstract}

JEL classification: O13, D12, I12

Keywords: affective test, experimental auction, biofortification, maize 


\section{Introduction}

In maize-based diets with limited variation, typical for rural populations in East and Southern Africa, inadequate intakes of quality protein and, specifically, of essential amino acids can be a significant public health problem (Ghosh, Suri, \& Uauy, 2012; P. L. Pellett \& Ghosh, 2004). Other dietary sources of these amino acids, in particular legumes and animal source foods, are often not available or are too expensive for nutritionally-vulnerable populations in low-income countries (Peter L. Pellett, 1996; Young \& Pellett, 1990). To counter this problem, maize varieties with higher levels of the essential amino acids lysine and tryptophan, also called quality protein maize or QPM, have been developed using conventional plan breeding methods (Atlin et al., 2010). Despite good progress in developing a range of varieties adapted to different ecologies with improved agronomic performance (Krivanek, De Groote, Gunaratna, Diallo, \& Friesen, 2007), their adoption has been limited. Therefore, more effort is needed to assure these varieties respond to both producers' and consumers' requirements, both in the field and post-harvest. Most research has, so far, focused on producer characteristics, largely ignoring consumer acceptance. A set of studies in different East African countries was, therefore, undertaken to assess consumer acceptance of QPM, of which the results for rural Tanzania are presented here.

Maize is a vital staple and a main source of dietary protein in many areas of the developing world. In southern African countries such as Malawi, Zambia, and Zimbabwe, per capita consumption of maize is more than $100 \mathrm{~kg}$ per year, while in Tanzania, per capita consumption is estimated at $73 \mathrm{~kg}$ per year (Food and Agriculture Organization, 2009), making it the most important staple food crop (Ministry of Agriculture and Cooperatives, 2001). It also serves as a key cash crop, and over $80 \%$ of the population depends on maize as a source of either food or cash (Moshi, 1997). Most maize in Tanzania (85\%) is produced by small-scale farmers, and most production is consumed at the household level (Moshi, 1997).

Methods to alleviate long-term nutritional deficiencies include dietary diversification, supplementation, fortification, and biofortification (Campos-Bowers \& Wittenmyer, 2007). Biofortification is the development, through plant breeding, of food crops rich in bioavailable micronutrients or essential amino acids (Johns \& Eyzaguirre, 2007) and does not rely on food 
processing such as fortification (H.E. Bouis, 1996) or repeat purchases or distribution such as supplementation (Johns \& Eyzaguirre, 2007), increasing its potential to benefit the rural poor. Biofortification targets rural areas where home production and consumption of staple food crops are significant, and ex ante studies indicate it is economic and cost efficient (Howarth E. Bouis, 1999; J. V. Meenakshi et al., 2010). Consumption of biofortified crops has been shown to improve nutritional status, in particular in studies with orange-fleshed sweet potato, high in betacarotene, in South Africa (van Jaarsveld et al., 2005) and Mozambique (Low et al., 2007) and with rice biofortified with iron in the Philippines (Haas et al., 2005).

The first biofortified crop was quality protein maize (QPM). It is conventionally bred to contain the opaque-2 gene, which roughly doubles the available protein in maize due to higher levels of the essential amino acids lysine and tryptophan (Vasal, 2000). A meta-analysis of nine nutritional studies showed that consumption of QPM instead of conventional maize (CM) leads to a $12 \%$ increase in the rate of growth in weight and a $9 \%$ increase in the rate of growth in height in infants and young children with mild to moderate under-nutrition from populations in which maize is the major staple food (Gunaratna, De Groote, Nestel, Pixley, \& McCabe, 2010). Modern QPM varieties are currently being actively disseminated, particularly in sub-Saharan Africa (Krivanek et al., 2007). Except for Ghana (Dankyi, Sallah, Adu-Appiah, \& GyameraAntwi, 2005) and Uganda (De Groote et al., 2009), which are not major maize countries, QPM varieties have not been particularly popular. The initial opaque-2 varieties had soft, chalky grains, which consumers often found undesirable (Vasal, 2000). However, decades of QPM development lead to improved agronomic performance and the restoring of conventional kernel characteristics. It cannot be assumed, however, that the sensory characteristics of QPM would be the same as conventional maize, hence the need for consumer acceptance studies.

In Colombia, a study with opaque-2 maize in six different food preparations found that consumers generally preferred it to conventional maize (Pardo, Mora, Paez, De Orstruss, \& De la Cruz-Villata, 1972), while consumers in Nigeria found no differences when comparing porridge made from QPM to that made from conventional maize (Martins, Jideani, Yusuf, \& Tahir, 2010). In Ghana, consumers compared four QPM varieties to two conventional varieties using two traditional preparations made from fermented maize dough (kenkeyand tuozafi), and the QPM varieties generally performed better or equally well (Ahenkora, Twumasi-Afriyie, \& Obeng- 
Antwi, 1999). East Africa is the latest area of dissemination of QPM varieties, but consumer acceptance has not yet been evaluated. Moreover, testing consumer acceptance by estimating their willingness to pay (WTP) with experimental methods has never been applied to QPM. The main objective of this study, therefore, was to develop methods appropriate for rural consumers, and to use them to determine their acceptance and willingness to pay for QPM in the northern region of Tanzania, as part of a regional study covering two other countries, Ethiopia and Kenya (reported elsewhere).

Consumer acceptance is necessary for farmers to adopt new agricultural technologies, but the study of Africa's rural consumers' appreciation of new products is fairly recent. Biofortification can substantially alter the sensory characteristics of the new varieties, in particular, the color and aroma of orange-fleshed sweet potato or vitamin A biofortified maize, and the grain texture of early opaque-2 varieties. Central location testing (CLT) has been applied to African consumers to compare rice of different varieties, origins, and cooking methods in Ghana (Keith Tomlins, Manful, Gayin, Kudjawu, \& Tamakloe, 2007; K. I. Tomlins, Manful, Larwer, \& Hammond, 2005), orange-fleshed sweet potatoes in Tanzania (K. Tomlins et al., 2004), and fermented cassava products in Nigeria (Keith Tomlins, Sanni, et al., 2007).

A second group of studies used CLT testing but combined with experimental auction methods to additionally explore willingness to pay. In a framed field experiment in Mozambique, after tasting orange maize biofortified with provitamin A, consumers generally preferred white maize, but a large share were willing to exchange it for yellow maize in an auction (R. Stevens \& Winter-Nelson, 2008). In West Africa, several studies combined affective tests, mostly consumer acceptance tests using hedonic rating scales, and experimental auctions to obtain WTP of urban consumers for different rice varieties and processing methods (Demont et al., 2012; Rutsaert, Demont, Ndourb, \& Tollens, 2009).

The use of experimental methods to assess WTP for new consumer products in developing countries is relatively new, and a wide range of methods are being tested (Morawetz, De Groote, \& Kimenju, 2011). Revealed preferences, elicited through experiments or auctions where real products exchange hands for real money, are generally preferred to stated preferences obtained through hypothetical methods such as contingent valuation or choice experiments (Shogren, 
2005). While the latter are generally much cheaper, respondents do not have an incentive to reveal their true preferences leading to hypothetical bias.

Experimental methods are easy to combine with CLT's, but these have two major limitations. First, the participants are generally not representative: they are typically drawn from volunteers in an urban market or from the staff or students at a research institute. Second, the testing environment and method of preparation may not be the same as when consuming the products at home.

Home-use testing (HUT) enables the product use at home to be explored and can overcome some of the limitation of CLT. This was explored with orange maize in Zambia which combined a choice experiment to elicit willingness to pay along with the provision of nutrition information with a home-use test (Meenakshi et al., 2012). A third study, also with orange maize, in rural Ghana, combined affective tests with different methods of eliciting WTP, and found that among consumers who are not given information, WTP is higher for conventional varieties, but after being given information on their nutritional value, the trend is reversed (Banerji et al., 2013).

Affective tests seek to assess the personal response (preference or acceptance) to a new product by a sample of representative consumers, while sensory evaluations are typically conducted by a trained panel, trying to objectively assess the sensory attributes of a new product. Therefore, combining affective tests with experimental methods is an interesting and feasible way of assessing consumer acceptance of new products and, at the same time, estimating the WTP to assess their potential market. For affective tests in rural areas with a dispersed population, CLT faces logistical problems because it requires transporting the participants as well as preparing and transporting the food. Home-use testing, where consumers test a product over several days under normal conditions in their home to avoid the novelty factor, is time consuming and expensive, and only a few products can be evaluated at a time. For the experimental part in rural areas with dispersed populations, the Becker-DeGroot-Marschak (BDM) mechanism, an individual simulated auction, is most convenient because it can be done in participants' households. 
For this study, a novel approach was developed based on past experience to evaluate rural consumers' appreciation of QPM using ugali, a stiff porridge that is the most common maize preparation in Tanzania. In a first step, CLTs were organized with a triangle test and affective tests to see if consumers can distinguish QPM ugali from its conventional counterpart and by which criteria. In a second step, the home-use test was modified so it could be executed in a single sitting with the two products prepared consecutively. Participating households, randomly selected, were asked to prepare the ugali from both QPM and CM. One household member, usually the household head or the head's spouse, was then asked to evaluate the two products, in alternate order for households visited by the same enumerator, for a limited number of sensory characteristics. Among households visited by the same enumerator, the two products were presented in alternating order. In the third step, the participants were asked to make a bid for maize flour from QPM and conventional maize using the BDM mechanism to estimate their WTP and the factors that affect it. To estimate the effect of information on their WTP, half of the participants, randomly assigned, were given information on the nutritional benefits of QPM.

The general objectives of the study were first to develop and test a method to assess rural consumers' appreciation and WTP for new maize varieties, and second to apply this method to evaluate consumer acceptance and WTP for QPM, and hence its potential market in Tanzania. The specific objectives of the study were: i) to compare the sensory characteristics of ugali made from QPM and conventional maize; ii) to determine consumers' acceptance of QPM through sensory evaluation of ugali; iii) to estimate rural consumer's willingness to pay for QPM flour; and iv) to determine the effect of information on QPM's nutritional quality on consumers' WTP.

\section{Methodology}

\subsection{Methods and products}

Consumers derive satisfaction not from goods themselves but from the attributes these provide (Lancaster, 1966). Hence, when studying the market for new products, we analyze consumers' appreciation of its different attributes with consumer acceptance or affective tests. Several methods are commonly used: laboratory tests, central location tests (CLT), in-store tests, and home-use tests (HUT) (Meilgaard, Civile, \& Carr, 2007). Laboratory tests typically use sensory evaluation, in which a trained panel tries to objectively assess the sensory qualities of the 
products, while CLT, in-store and HUT tests typically use affective (hedonic or acceptance) tests with a representative sample of the target population (Meilgaard et al., 2007).

The different methods all have strengths and weaknesses. Laboratory tests use a more controlled environment, but the weakness is that it is not a typical consumer environment. In CLT, we take the test to the consumer; the testing environment, which can be a market or a restaurant, is more familiar to the consumer; and the test is still relatively cheap to conduct. However, some control is lost: the novelty of the product and environment can affect the evaluation; often the participants are not randomly selected to represent the target population; and the contact time with the consumer can be short. In HUT, the product can be tested with more time in the familiar home environment, but the cost is high and there is little control. It is generally assumed that a more realistic HUT yields more relevant hedonic data than CLT despite the uncontrolled conditions (Boutrolle, Delarue, Arranz, Rogeaux, \& Köster, 2007), and these tests have been compared by several studies. One study found a remarkably good agreement between the HUT and CLT scores (Griffin \& Stauffer, 1990), a second found good agreement although HUT scores tended to be higher than CLT scores (Boutrolle, Arranz, Rogeaux, \& Delarue, 2005; Boutrolle et al., 2007), and this was confirmed by a third study which did find, however, that for some products the two methods led to different conclusions (Boutrolle et al., 2007).

HUT was used to test this product because maize is most commonly consumed at home and we wanted the consumers to have time to become familiar with the product. Householders prepare the product in their usual way, and the respondents have repeated use of the product before evaluating it. For two products, the households prepare and use them consecutively. Because in HUT, the products are evaluated in the consumers' normal environment and over a period of time, the evaluation is based on a stabilized use rather than a first impression (Meilgaard et al., 2007).

Unfortunately, the long evaluation time in HUT make affective tests time-consuming and expensive with rural populations in developing countries, especially when a representative sample is desired. Results of a HUT study in Zambia evaluating provitamin A orange maize, however, indicated that a longer evaluation time was not critical, but that thirty minutes is likely 
to be sufficient for rural consumers to form an opinion about the product (J.V. Meenakshi et al., 2010). Therefore, for this study, the HUT was modified and reduced to a single evaluation, but at the houses of randomly-selected rural consumers, based on food prepared in their kitchen following their standard procedures, followed by a BDM mechanism to determine WTP. To guide this exercise, a triangle test was conducted in a CLT in a peri-urban centre, to see if QPM ugali can be distinguished from ugali made from conventional maize, followed by a sensory evaluation to see which characteristics were distinguishable and different. The triangle test would be difficult to combine with a HUT, so it was organized with the CLT at the agricultural research center (SARI), which is situated on the outskirts of Arusha and has staff who were wellintegrated and similar to people from the surrounding rural households..

To evaluate rural consumers' appreciation of QPM, the most common maize preparation in Tanzania was chosen. Ugali is a stiff porridge prepared by mixing maize flour in boiling water for about ten minutes. To compare QPM with conventional maize, ideally near-isogenic varieties should be used: varieties that are nearly identical except for the QPM trait. Unfortunately, these were not available in Tanzania. Therefore, the oldest and most used QPM variety in Tanzania was chosen (Lishe K1) and compared to a conventional common maize variety. Both maize varieties were purchased in the local market and milled according to local preferences, in hammer mills without de-hulling. The flour was coded with labels: a triangle for QPM flour and a circle for conventional maize. These symbols do not have a particular connotation in this area and are preferred to numbers which might affect the judgment of the respondents (Watts, Ylimaki, Jeffery, \& Elias, 1989). The same varieties were used in the three districts.

\subsection{Study design and data collection}

\subsubsection{Central location test (CLT)}

The CLT test consisted of the triangle test and hedonic scoring. The triangle test is the standard procedure to determine whether sensory differences exist between two products (Meilgaard et al., 2007). It was carried out at the Selian Agricultural Research Institute (SARI) with 30 employees in January 2010. After administering a short questionnaire, the test was 
conducted with samples of ugali made from either QPM or conventional maize. The products were prepared by the same cook, who only knew the different products by their label (a triangle for QPM and a circle for conventional maize) but not their meaning. Each respondent was then presented simultaneously with three samples of ugali: two of one type of maize and one of the other. The triangle test requires that each of the three samples have a different label, so here three-digit codes were used, assigned by the supervisor and not known to the participants or the enumerators who administered the test. The presented samples alternated between including two samples of QPM or two samples of conventional maize (CM), and participants were asked to choose the odd sample by any method of sensory evaluation. The test was followed by the hedonic evaluation, in which ugali samples of both batches, again marked with a triangle or circle, were served to the 30 participants in alternate order. Participants were asked to evaluate the samples, one at a time, for the five major attributes (aroma, appearance, texture in the hand, texture in the mouth, taste) and overall qualities. Because the participants were educated and had done similar exercises before, a 9-point Likert scale was used ( 1 = extremely bad, 2 = very bad, 3 $=$ bad, $4=$ moderately bad, $5=$ fair, $6=$ moderately good, $7=\operatorname{good}, 8=$ very good, and $9=$ extremely good). Water was provided to cleanse the palate between evaluations.

\subsubsection{Sampling design for rural consumers}

The rural consumers were selected from a household survey conducted in 2008 by the QPM Development (QPMD) project in its most important districts: Hai, Karatu and Babati, all in northern Tanzania (Fig. 1)(De Groote et al., 2009). The survey used a two-stage stratified sampling design with villages, the lowest administrative unit in the country, as primary sampling units. The villages in the selected districts were split into two strata: target villages for the QPMD project, where many QPM extension activities took place (field days, on-farm trials, seminars, and so forth), and control villages where no activities took place. Consumers from villages with access to the QPMD extension activities are likely to be more familiar with QPM, which can influence their appreciation of the derived food products. In each stratum, 15 villages were randomly sampled with probability proportional to size, measured in the number of households. Within each village, ten households were selected by simple random sampling, giving 300 in total. For this study, 12 villages were randomly sampled from the 15 villages in each stratum, and because some households could not be traced, a total of 120 households were 
interviewed, 58 from the QPMD target villages, and 62 from the other villages. The selected households were visited from January to February 2010 by eight trained enumerators from SARI, using specially developed and tested tools. Alternately the household head or the spouse of the head participated. First, an interview was conducted, covering the socioeconomic characteristics of the participant and household, and the participant's awareness of protein and QPM. This was followed by the consumer acceptance test, the provision of information on the nutritional benefits to a random subset of participants (66 participants), and finally the WTP experiment.

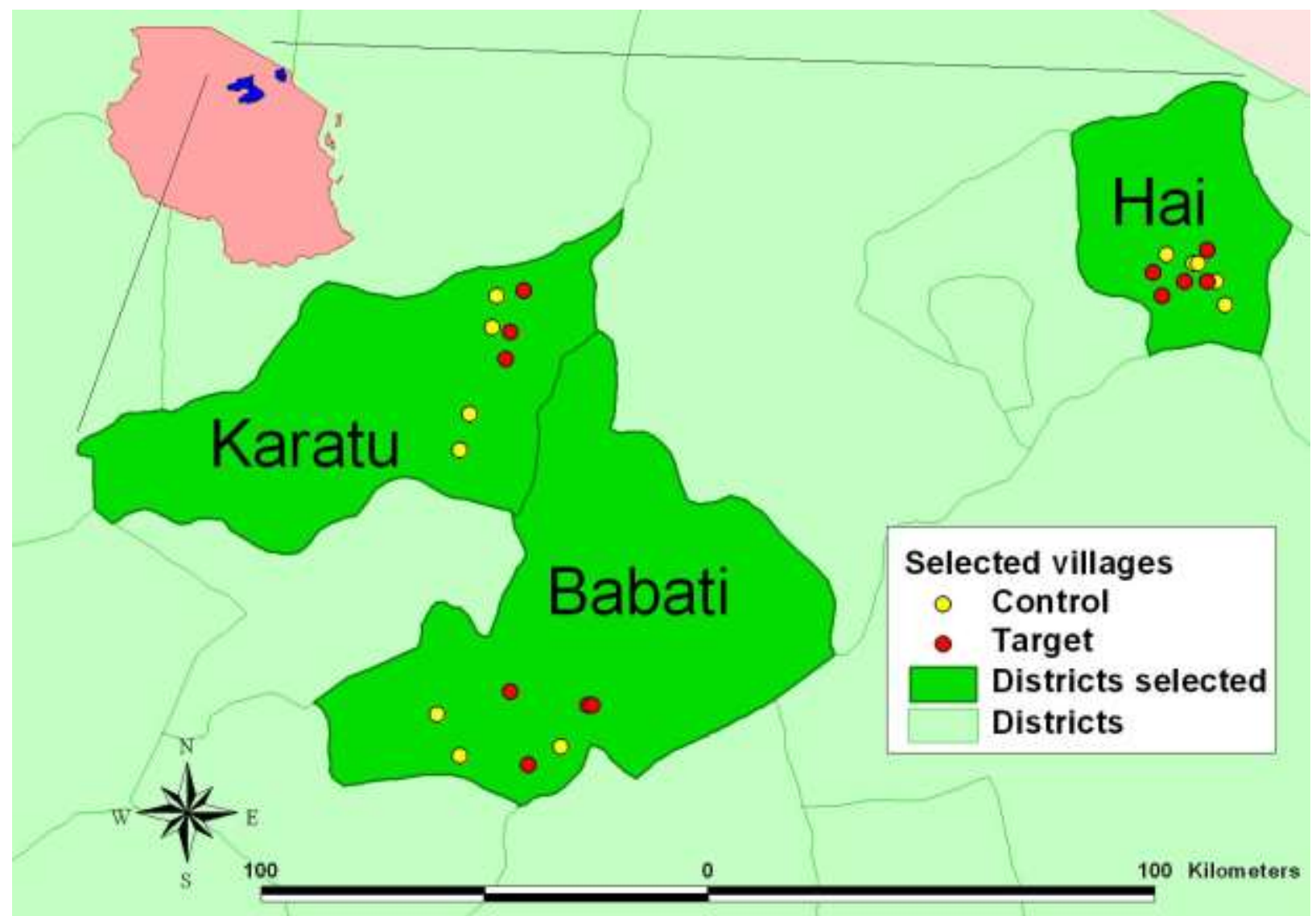

Fig. 1. Map of QPMD project target villages and controlvillages for HUT and WTPstudies

\subsubsection{Modified Home-Use Test}

The maize for the modified home-use test was purchased, milled and labelled in the same way as for the CLT. The person responsible for cooking in the household, usually the wife of the household head, was asked to prepare ugali from both batches separately, in her own kitchen using her regular utensils. The respondents, 120 in total, were asked to evaluate the ugali from each of their own batches, one at a time and in alternate order, for texture in the hand, texture in 
the mouth, taste and overall evaluation, each on a 5-level hedonic scale, from $1=$ very bad to $5=$ very good. (See Appendix 1 for the terms used in the local language, Swahili.) The 5-point scale was chosen because many of the respondents were illiterate, and this scale is easy to use orally in any language and for any criteria.

\subsubsection{Estimating willingness to pay with experimental auctions}

Eliciting willingness to pay (WTP) from consumers adds an economic dimension to the overall evaluation. The resulting money metric is a ratio variable: in contrast to the ordinal variables of the hedonic scale, its values have a concrete meaning (S. S. Stevens, 1946), and they can be compared across evaluations. WTP can be estimated through hypothetical methods such as contingent valuation (Kimenju \& De Groote, 2008) or choice experiments (Bennett \& Birol, 2010). These methods are cheap and convenient, but consumers only state their preferences, which can lead to hypothetical bias (Shogren, 2005). Choice experiments can be incentivized by showing the real product and offering an incentive that reflects the choice expressed in the experiment, for example as was done in a study on orange flesh sweet potatoes in Mozambique, although the authors concede this does not make the experiment incentive compatible (Naico \& Lusk, 2010). Incentive compatibility can be achieved by making one of the choices binding and letting the participant purchase the outcome of the choice, as has been demonstrated with orange maize, biofortified with provitamin A, in Zambia (Chowdhury, Meenakshi, Tomlins, \& Owori, 2011) and in Ghana (Banerji et al., 2013). The drawback of this method is the number of inconsistent responses, lexicographic preferences, and the high variation in the estimated WTP (Banerji et al., 2013).

The most common procedure to elicit revealed preferences are experimental auctions such as the Vickrey and $n^{\text {th }}$ price auctions, which are incentive compatible: it is in the participants' interest to reveal their true WTP (Lusk, Feldkamp, \& Schroeder, 2004). Where people are concentrated in villages, auctions can conveniently be held by assembling the participants, which can easily be combined with CLT, such as in rural Ghana (De Groote, Tomlins, et al., 2010b). Group auctions are, however, time consuming and costly for a rural population with dispersed housing. Other types of group auctions, such as soliciting bids through sealed envelopes, by phone or over the internet, are also not convenient with a dispersed rural population in 
developing countries. For such populations, however, the Becker-DeGroot-Marschak (BDM) mechanism (Becker, DeGroot, \& Marschak, 1964) provides a convenient alternative, in which participants bid against a number drawn from a random distribution, mimicking an auction. Respondents whose bid exceeds the randomly drawn price win the auction and purchase the good at the random price. The procedure is conducted individually and can, therefore, be applied with a randomly selected population and conveniently combined with the modified HUT in the homestead. Its use for African rural consumers can be justified on theoretical, as well as practical, grounds (Morawetz et al., 2011). It has been used to study consumers' acceptance of yellow maize in Ghana (De Groote, Tomlins, et al., 2010a) and Kenya (De Groote \& Kimenju, 2008), and for aflatoxin-free maize in Kenya (De Groote, Narrod, Bett, Scott, \& Tiongco, 2011).

In this study, the BDM mechanism was used after the consumer acceptance test. First, the mechanism was explained, and a test round was organized with cupcakes to familiarize the participants with the mechanism. Participants were given TSh200 (\$US0.15), and asked to make a bid for two different types of cupcakes. One was randomly selected as binding; the participant drew a number from a random distribution and, if the bid exceeded the number, the participant won the auction and bought the cake at the random price.

Then, participants were given TSh600 (US\$0.45), about TSh100 more than the price of $1 \mathrm{~kg}$ of maize flour, and invited to make a bid for the products they had just evaluated: flour from QPM and conventional maize, packaged in clear plastic bags of $1 \mathrm{~kg}$ and labeled with a circle or a triangle, respectively. Half of the respondents in each stratum (selected by the enumerator by alternating between consecutive respondents) were told which product was QPM and read a short information message, explaining the improved nutritional quality of QPM (see Appendix 2). In total 66 participants got QPM nutritional information (30 from control villages and 36 from target villages) and 54 did not receive the information (28 from control villages and 26 from target villages).

After making their bids, one product was randomly selected. Participants drew a number from a bag with random numbers from 100 to 250 for the test round, and from 400 to 600 for the actual round. These numbers were generated from a normal distribution with a mean equal to the average price of the products (cupcakes and maize flour, respectively) and rounded to the closest 
multiple of 50. If the participant's bid was higher than the number drawn, they bought the product at the random price. Participants were informed of the procedure and that the bag contained random numbers, but not of their distribution. After the test round there was an opportunity to ask questions, but not to inspect the numbers in the bag.

\subsection{Analysis}

\subsubsection{Triangle test}

If ugali made from QPM were indistinguishable from ugali made from conventional maize, the number of correct responses from 30 participants follows a binomial distribution with sample size 30 and probability of success 1/3 (Meilgaard et al., 2007), so this distribution was used to test the alternative.

\subsubsection{Consumer acceptance}

In consumer acceptance or affective tests, consumers are typically asked to evaluate new products on a Likert scale, in which the responses are ordered but not necessarily equally spaced (Coe, 2002). In this study, a 9-point scale was used for the CLT, and a 5-point scale for HUT. The 9-point scale arguably approximates an interval variable, and can, therefore, be analyzed using standard statistical methods such as a pair-wise comparison of means. This is more problematic for the 5-point scale, where the scores represent an ordered, rather than an interval, variable, and should be analyzed using appropriate methods such as ordinal regression (Coe, 2002; De Groote, Rutto, et al., 2010; McCullagh, 1980). The five-point scale has the advantage that it can be used on any criterion in any language. Finally, because the same consumer is asked to evaluate different products, these evaluations are likely to be related. Including a random subject effect in the analysis would account for correlation among observations from the same participant (Green, 2008).

Ordered-response models assume that the scores represent ordered segments of a utility distribution (Maddala, 1983), p. 46):

$$
U_{i}=\boldsymbol{\beta}^{\prime} \boldsymbol{x}_{i}+\varepsilon_{i}
$$


where $\boldsymbol{x}_{i}$ is a vector of variables influencing the $i^{\text {th }}$ individual's utility, $\boldsymbol{\beta}$ is a vector of parameters, and $\varepsilon_{i}$ is the random error term. The probability of the scores $y$ can be derived in function of $\boldsymbol{x}_{i}$ and assuming $\varepsilon_{i}$ has a logistic distribution (Train, 2003), by constructing and maximizing the log-likelihood function . Let $v_{\mathrm{k}}=P(y \leq k)$, or the probability that a score $y$ falls at or below a certain level $k$, and the logit (logarithm of the odds) of $v_{\mathrm{k}}$ is a linear function of the independent variables:

$$
\operatorname{Logit}\left(v_{k}\right)=\operatorname{Ln} \frac{P(y \leq k)}{1-P(y \leq k)}=\theta_{k}+\beta^{\prime} \mathbf{x},
$$

where $\theta_{k}$ is an intercept specific to level $k$. The effects $\beta$ do not depend on the level $k$, and this model is, therefore, called the proportional odds model (McCullagh, 1980) or the ordered logit model (Greene, 1991; Train, 2003). The coefficient $\boldsymbol{\beta}$ represents a change in the log odds for a unit change in the explanatory variable $x$. If $x$ is binary, as when comparing a new product to an old one, the coefficient $\beta$ represents the change in the log odds due to the new product or also called the log odds ratio. Its exponentiale ${ }^{\beta}$ represents the odds that the new product is rated higher over the odds for the old product (Bellon, Adato, Becerril, \& Mindek, 2006; De Groote et al., 2014 (forthcoming)).

In this study, only two products are evaluated, QPM and CM, represented by a binary variable $q$ ( $q=1$ for $Q P M, 0$ otherwise). Formally, the dependent variable is $y_{i j}$, the score the consumer $i$ gives to product $j$ for a particular sensory characteristic. The vector of explanatory variables $\boldsymbol{x}$ contains the variables describing the study design (if the village was a QPMD project village, the different districts, and the order of presentation) with random individual effect $u_{i}$ assumed to be normally distributed with mean 0 and variance $\sigma_{u}^{2}$, and the basic model becomes:

$$
\operatorname{Logit}\left(v_{i j k}\right)=\theta_{k}+\alpha_{q} q+\boldsymbol{\beta}_{c} \boldsymbol{x}^{\prime}+\boldsymbol{\beta}_{q}^{\prime} \boldsymbol{x} q+u_{i}
$$

The effect of QPM on the consumer acceptance score is estimated by $\alpha_{q}$ while the effects of the design variables on conventional maize and QPM are estimated by $\boldsymbol{\beta}_{\boldsymbol{c}}$ and $\boldsymbol{\beta}_{\boldsymbol{q}}$, respectively.

Evaluation of new products can also differ by the characteristics of the consumers, in particular gender, education, and age, which can be included as a vector $z_{i}$ in the expanded model (De Groote, Kimenju, \& Morawetz, 2011):

$$
\operatorname{Logit}\left(v_{i j k}\right)=\theta_{k}+\alpha_{q} q+\boldsymbol{\beta}_{c}{ }^{\prime} \boldsymbol{x}+\boldsymbol{\beta}_{q}{ }^{\prime} \boldsymbol{x} q+\gamma_{c}{ }^{\prime} z_{i}+\gamma_{q} z_{i} q+u_{j}
$$


These models were evaluated using a mixed-effects ordinal logistic regression model (McCulloch C.E., Searle S.R., \& J.M, 2008) using SAS statistical software. If $\sigma^{2}{ }_{u}$ was estimated at zero, a fixed effects model was used.

\subsubsection{Willingness to Pay}

The bids in the BDM mechanism are unbiased estimates of consumers' WTP, so the sample mean is an unbiased estimate of the population mean and the mean bids for QPM and CM flour can be compared using paired-samples t-tests. Further, to account for the design of the study, this was followed by a formal analysis with a linear regression model with random effects. Formally, let $b_{i j}$ be the bid of consumer $i$ for product $j$ :

$$
b_{i j}=\alpha_{c}+\alpha_{q} q+\boldsymbol{\beta}_{c}{ }^{\prime} \boldsymbol{x}+\boldsymbol{\beta}_{q}{ }^{\prime} \boldsymbol{x} q+u_{i}+v_{i j}
$$

To model the effects of the study design, $x$, a binary variable was added indicating if the respondent had received information on QPM. Further, the effects of individual and household characteristics were analyzed using a longer model:

$$
b_{i j}=\alpha_{c}+\alpha_{q} q+\boldsymbol{\beta}_{c}{ }^{\prime} \boldsymbol{x}+\boldsymbol{\beta}_{q}{ }^{\prime} \boldsymbol{x} q+\gamma_{c} \boldsymbol{z}_{i}+\gamma_{q} z_{i} q+u_{i}+v_{i j}
$$

This model uses the same explanatory variables as for the affective test, plus awareness of QPM and wealth effects, such as non-agricultural income and land owned. To analyze the effect of the sensory evaluation on WTP, its overall score was also included.

\section{Results}

\subsection{Central location test}

Thirty respondents participated in the CLT, all volunteers from the staff of SARI, including 12 women. The average age was 42 years (from 18 to 56). All participants had at least completed primary education; most $(90 \%)$ had also completed secondary education and half had, at least, some tertiary education. 
In the triangle test, 21 respondents (70\%) correctly identified the odd sample. This was significantly greater than the number that could be expected from random guessing $(\mathrm{P}<0.001)$ (the critical value from the binomial distribution with $p=1 / 3$ and $n=30$ would be 14 at a 0.05 significance level), indicating that consumers could differentiate ugali made from QPM versus conventional maize in a double-blind test based on sensory characteristics.

In the double-blind affective test, respondents consistently scored QPM ugali significantly higher than conventional maize ugali for aroma, taste, texture in the mouth and the hand, and overall (Fig. 2). There was no significant difference in appearance, indicating that both varieties have a similar color and are not visually distinctive.

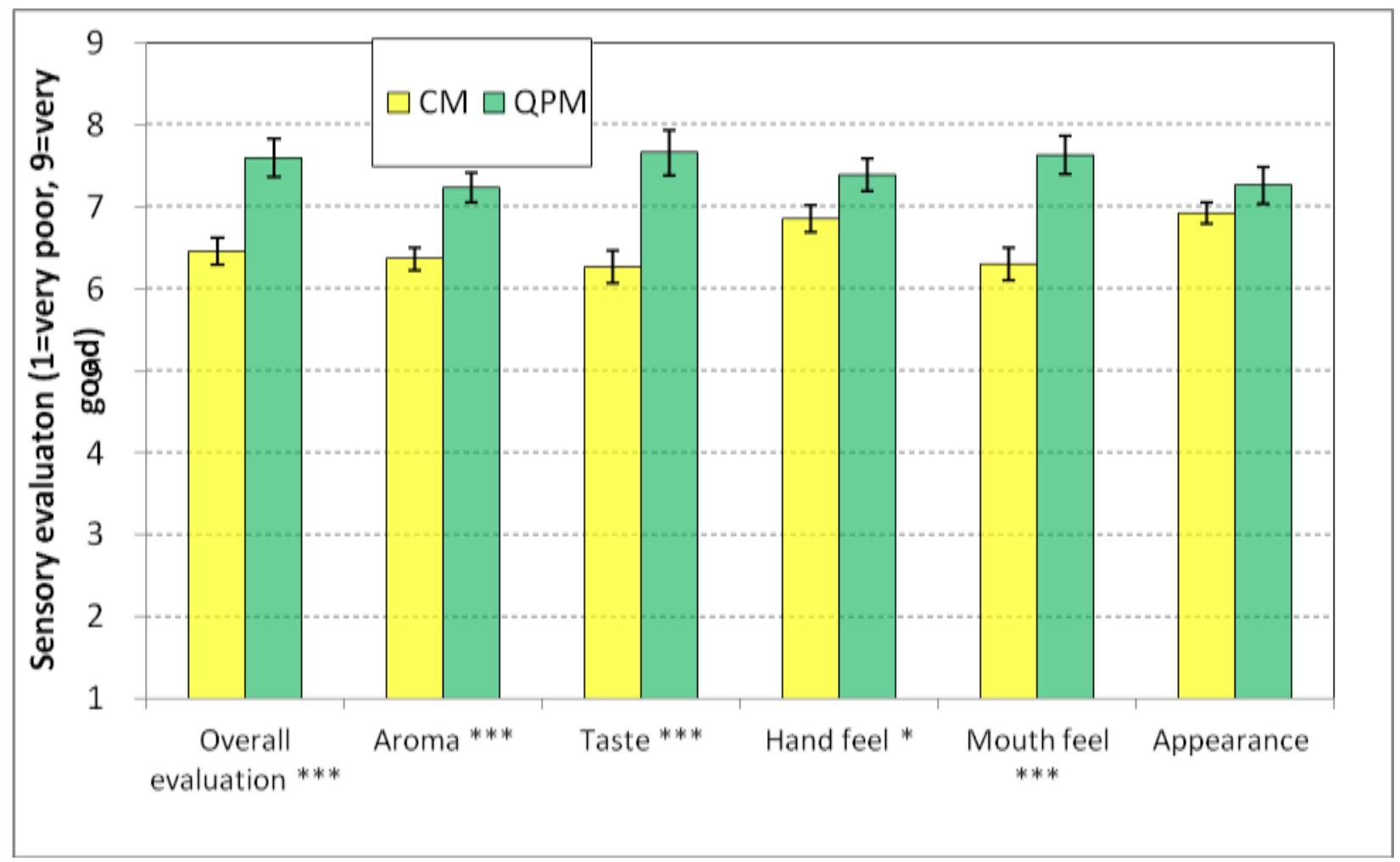

Fig. 2. Pairwise comparison of the evaluation of ugali from QPM and conventional maize (CM) during central location sensory testing, for the five criteria and overall $(\mathrm{N}=30)$

${ }^{* * *}=\mathrm{P}<0.001 ;{ }^{* *}=\mathrm{P}<0.01 ;{ }^{*}=\mathrm{P}<0.05$

\subsection{Rural consumers' characteristics, food preparations, and awareness of QPM}

All selected households were visited at their homestead and alternately the head and the head's spouse were interviewed, so about half the respondents were women. The average age of respondents was 49 years (Table 1). The average non-agricultural income received by 
Table 1

Characteristics of rural respondents and their farms, by district

\begin{tabular}{|c|c|c|c|c|c|c|c|c|c|}
\hline \multirow[t]{2}{*}{ Type } & \multirow[t]{2}{*}{ Characteristic } & \multicolumn{2}{|c|}{ Babati $(n=36)$} & \multicolumn{2}{|c|}{ Hai $(n=48)$} & \multicolumn{2}{|c|}{ Karatu $(n=36)$} & \multicolumn{2}{|c|}{ Overall (120) } \\
\hline & & Mean & $\begin{array}{l}\text { Std } \\
\text { dev. }\end{array}$ & Mean & $\begin{array}{l}\text { Std } \\
\text { dev. }\end{array}$ & Mean & $\begin{array}{l}\text { Std } \\
\text { dev. }\end{array}$ & Mean & $\begin{array}{l}\text { Std } \\
\text { dev. }\end{array}$ \\
\hline \multirow[t]{4}{*}{ Individual } & Female $(\%)$ & 42 & 1 & 44 & 1 & 47 & 1 & 44 & 0 \\
\hline & Respondent Age (years) & 44 & 9 & 52 & 10 & 48 & 14 & 49 & 11 \\
\hline & Years in formal education & 6 & 2 & 8 & 2 & 6 & 2 & 7 & 2 \\
\hline & $1000)^{\text {a }}$ & 474 & 848 & 1535 & 3984 & 428 & 716 & 885 & 2638 \\
\hline \multirow[t]{6}{*}{ Farm } & Total livestock owned & 21 & 16 & 19 & 16 & 17 & 15 & 19 & 16 \\
\hline & Total land owned (ha) & 2.4 & 2.6 & 1.1 & 0.9 & 2.4 & 2.7 & 1.9 & 2.2 \\
\hline & Total land cultivated (ha) & 2.3 & 2.3 & 1.4 & 1.8 & 1.9 & 1.5 & 1.8 & 1.9 \\
\hline & Land under maize (ha) & 1.9 & 2.0 & 1.1 & 1.7 & 1.6 & 1.3 & 1.5 & 1.7 \\
\hline & $\begin{array}{l}\text { Maize produced on an average year (tons) } \\
\text { Proportion of own maize consumed in household }\end{array}$ & 4.5 & 4.1 & 2.6 & 2.3 & 3.1 & 2.4 & 3.3 & 3.1 \\
\hline & (\%) & 50 & 25 & 55 & 26 & 58 & 31 & 54 & 27 \\
\hline
\end{tabular}

${ }^{\mathrm{a}} \mathrm{US} \$ 1=\mathrm{TSh} 1,347$ 
households during 2009 was TSh885,000 (US\$657), but it was substantially higher in Hai than in Babati and Karatu. Out of an average 1.8 ha of land cultivated per household during the 2008/2009 main season, 1.5 ha was planted with maize. The respondents in Babati had the highest average cultivated area (2.3 ha) and maize area (1.9 ha). In an average year, each household produced around 3.3 tons of maize, of which 54\% was consumed at home. Respondents in Babati had the highest annual maize production (4.5 tons).

To confirm that the home-use test used the most relevant food preparation, respondents were asked to state their most common foods for breakfast, lunch and dinner. Maize was by far the dominant crop, but breakfast preparations are usually different from lunch and dinner (Fig. 3). At breakfast, porridge ( $u j i$ in Swahili) is the most common meal, almost uniquely made from maize, usually with milk and sugar. The second most important preparation for breakfast is tea, usually prepared with milk and sugar, followed by ugali. Wheat is, after maize, the second most common food crop for breakfast. Ugali is by far the most common food for lunch (mentioned first by $92 \%$ of respondents) and for dinner (67\%). Other common preparations for lunch and dinner are cooked bananas, makande (a stew with whole maize kernels), and rice.

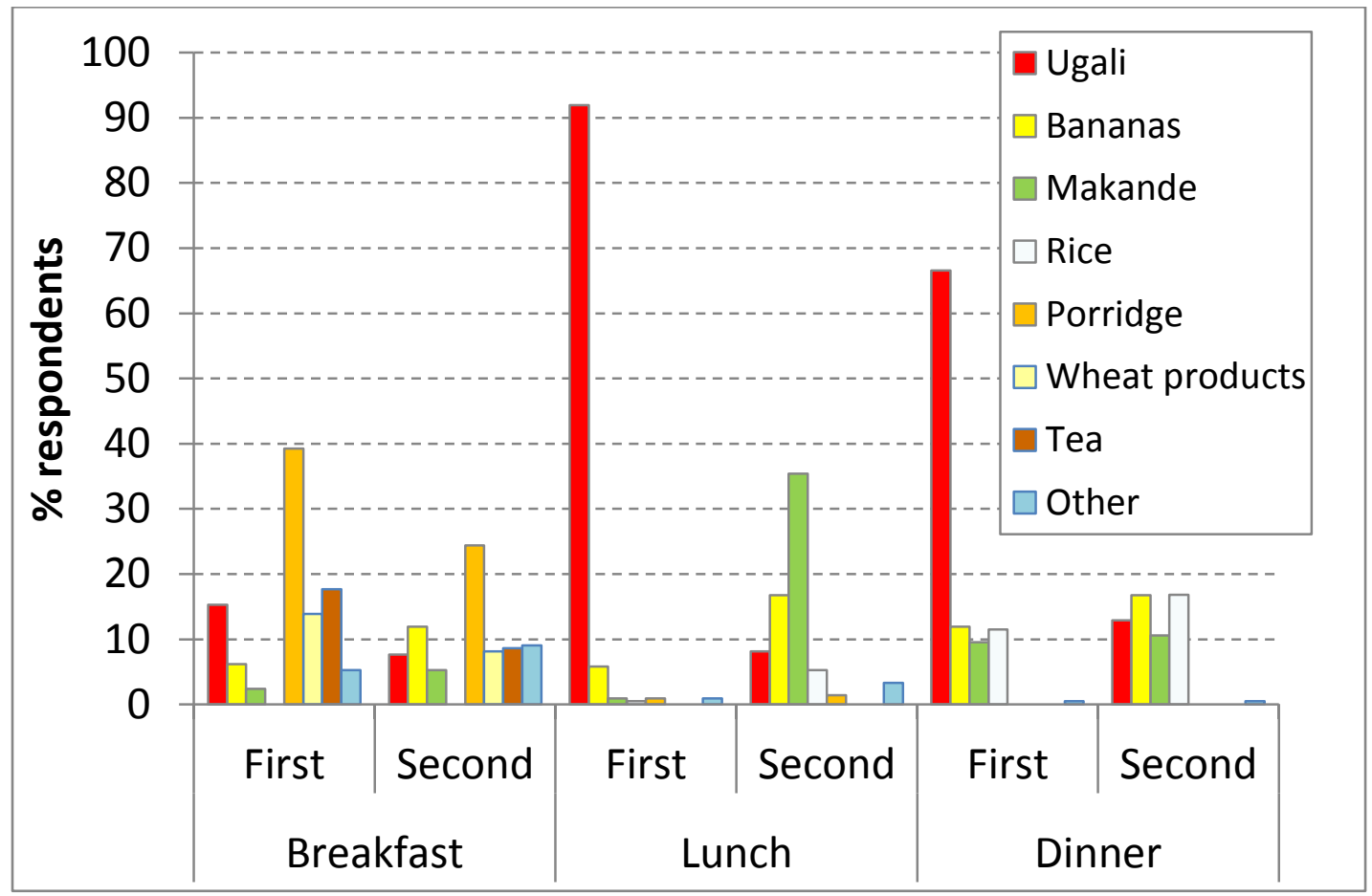

Fig. 3. The first and second most common food preparations for breakfast, lunch and dinner in rural households in Northern Tanzania 
In the villages where the QPMD project had been active, awareness of QPM was high, especially in Babati (100\%) and Hai (92\%), and somewhat less in Karatu (75\%) (Fig. 4).This is understandable because farmers in these villages had access to the project's activities, and $41 \%$ of respondents from these villages participated, mostly attending the field days (18\%), on-farm trials $(6 \%)$, and seminars $(5 \%)$. In the control villages, where only $7 \%$ of respondents participated in project activities, awareness was much lower: still, more than half the respondents in Babati were aware of QPM, but only a third in the other districts. Awareness of protein in the three districts was high: more than three quarters of respondents from both the target and control villages were aware of protein, with little differences between the two groups.

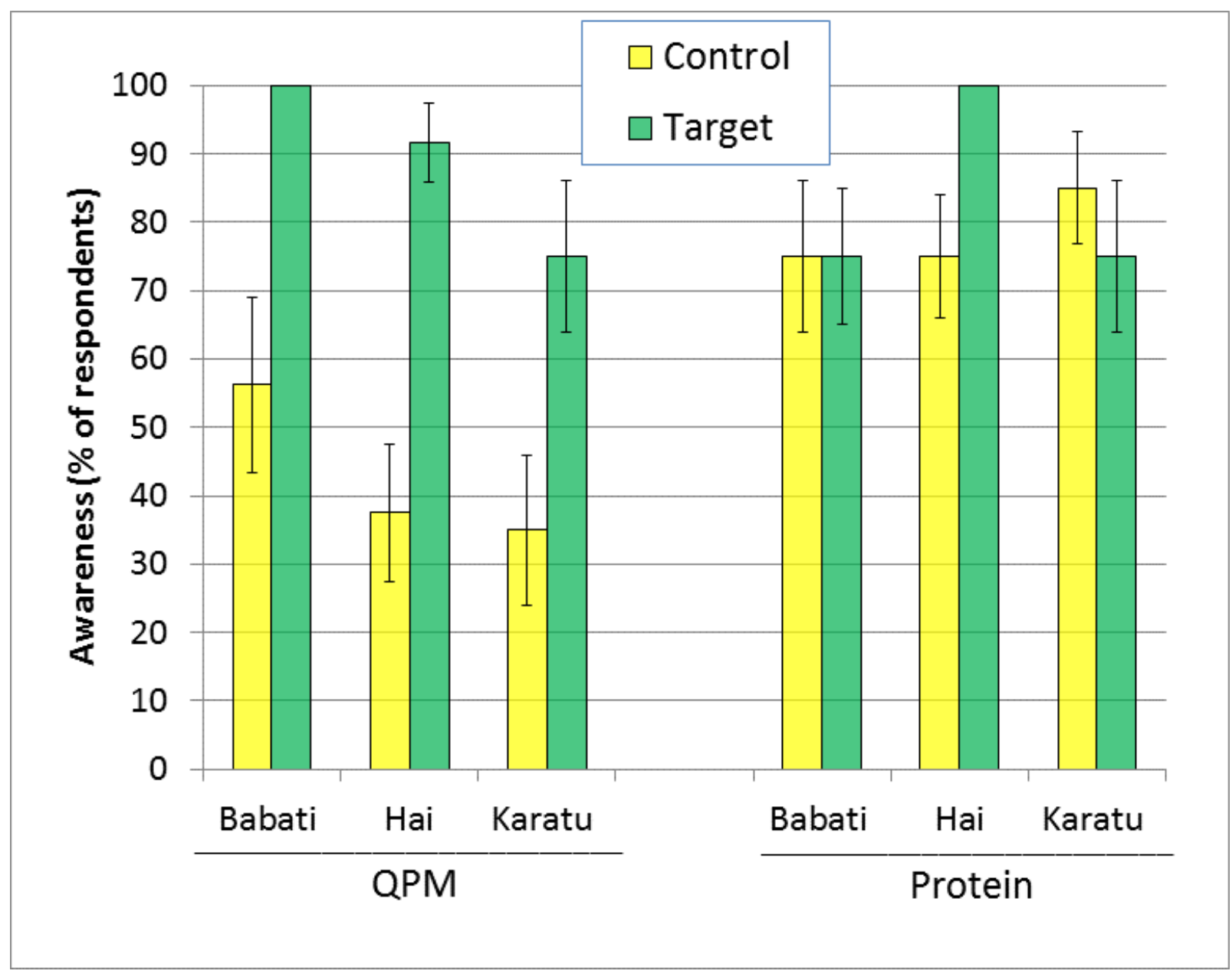

Fig. 4. Rural respondents' awareness of QPM and protein, by stratum and district 


\subsection{Modified home-use testing with rural consumers}

After the interview, the participating households were given two batches of maize flour, one from QPM and one from conventional maize, again labeled with a triangle and a circle, respectively. The person responsible for cooking was asked to prepare ugali from both batches, and the respondent was asked to evaluate the ugali for its major sensory characteristics on a fivepoint scale. None of the participants used the lowest category ("very bad"), however, and only $3 \%$ the second lowest category ("bad"), so almost all responses were in the top three categories (Table 2). Still, there was a clear distinction between the scores for QPM and conventional maize, with QPM consistently scoring roughly one category higher than conventional maize.

Most participants scored conventional maize overall as fair (58\%) or good (38\%), while scoring the QPM as good (33\%) or very good (61\%). For hand feel, most respondents scored conventional maize as fair (66\%) and QPM as good (67\%). For mouth feel most respondents scored conventional maize as fair (53\%) or good (41\%), and QPM as good (55\%) or very good (35\%). Finally, for taste, most respondents evaluated conventional maize as fair (50\%) or good (48\%), while a majority of respondents scored QPM as very good (58\%).

Because scores are ordered categorical data, they were analyzed with ordinal regression, first using the short model of Equation 3 with the design variables only, which include binary variables for the QPMD project target village, the different districts, and the order of presentation. Ugali made from the QPM variety is more appreciated than that from conventional maize: in the regressions on the scores for texture in hand, texture in mouth, taste and overall qualities, the coefficients on QPM are large, positive and significant (Table 3). These coefficients are log odds ratios: for texture in hand. For example, QPM has a log odds ratio of 2.7 or an odds ratio of 15 (the exponential of 2.7). This indicates that the odds of QPM ugali being rated higher is 15 times higher than the odds of the conventional variety being rated higher. The coefficients for the other criteria are slightly higher, indicating a higher odds ratio.

Because there are only two products, the main effects reflect the effect on conventional maize (CM), the omitted category. Some differences are observed in consumer acceptance between districts. Only the coefficient on Babati is significant, and only on texture in mouth, 
Table 2

Consumer acceptance scores for ugali made from QPM or conventional (CM) among rural consumers (\% of respondents scoring product in that category for that attribute, $n=120$ )

\begin{tabular}{|c|c|c|c|c|c|c|c|c|}
\hline \multirow[t]{2}{*}{ Score } & \multicolumn{2}{|c|}{ Overall } & \multicolumn{2}{|c|}{ Texture in hand } & \multicolumn{2}{|c|}{ Texture in mouth } & \multicolumn{2}{|c|}{ Taste } \\
\hline & $\mathrm{CM}(\%)$ & QPM $(\%)$ & $\mathrm{CM}(\%)$ & QPM $(\%)$ & $\mathrm{CM}(\%)$ & QPM $(\%)$ & $\mathrm{CM}(\%)$ & QPM $(\%)$ \\
\hline Very bad & 0 & 0 & 0 & 0 & 0 & 0 & 0 & 0 \\
\hline $\mathrm{Bad}$ & 0 & 0 & 0 & 0 & 3 & 0 & 1 & 0 \\
\hline Fair & 58 & 7 & 66 & 13 & 53 & 10 & 50 & 10 \\
\hline Good & 38 & 33 & 33 & 67 & 41 & 55 & 48 & 32 \\
\hline Very good & 5 & 61 & 1 & 21 & 3 & 35 & 2 & 58 \\
\hline
\end{tabular}


indicating that $\mathrm{CM}$ scores are better here than in the other districts on this criterion (although still lower than QPM). The cross effect of Hai with QPM, however, is significant for both texture and overall qualities. The cross effect of target villages with QPM is not significant, indicating that consumer acceptance was not different there from the control villages. There is also an order effect: when QPM was presented first, it tended to get a lower score than when it was presented second. There was no significant order effect for CM, though.

To estimate the effect of consumer characteristics, they were included in the long model of Equation 4. Neither gender, age, nor education had an effect on the scores for any criterion or overall qualities (only the last one is presented in the last column of Table 3), but they did increase the standard errors of the other coefficients, reducing their statistical significance.

\subsection{Estimating rural consumers' willingness to pay (WTP) with experimental auctions}

After the affective test, half the respondents received information on the nutritional quality of QPM. All respondents were invited to make bids for both the QPM and CM flour during the BDM exercise. Those who did not receive the information were assumed to make their bids based on the affective test, because they were not informed of the name or nutritional quality of the two varieties. Their bids for QPM maize flour (an average of TSh498) were substantially and significantly higher than those for conventional maize (TSh418 on average): a difference of TSh80/kg (US\$0.06) or a premium of 16\% (Fig. 5).

The respondents who received information on QPM were assumed to make their bids based on the affective test as well as on the information that QPM has a higher nutritional quality than conventional maize and is possibly based on previous knowledge of QPM. The result was, as expected, an increase in WTP for QPM, but also a reduction in WTP for conventional maize. The information provided increased respondents' WTP for QPM by only 5\%, but it also reduced their WTP for conventional maize by 10\% (to TSh377), leading to an overall premium of $39 \%$ (TSh148). This pattern is seen in all districts, although with some clear differences: the premium is highest in Karatu and lowest in Babati, and this for both groups (Table 4). None of the respondents made zero bids; the minimum bid was TSh 200, and only one respondent's bid (of TSh 700) exceeded the cash amount provided. 
Table 3

Factors influencing rural consumers' acceptance scores of ugali made from QPM and CM (ordinal regression models, dependent variable is score for sensory evaluation)

\begin{tabular}{|c|c|c|c|c|c|c|c|c|c|c|c|}
\hline \multirow[t]{2}{*}{ Group } & \multirow[t]{2}{*}{ Variable } & \multicolumn{2}{|c|}{ Texture in hand } & \multicolumn{2}{|c|}{ Texture in mouth } & \multicolumn{2}{|c|}{ Taste } & \multicolumn{2}{|c|}{ Overall } & \multicolumn{2}{|c|}{ Overall } \\
\hline & & Coeff. & SE & Coeff. & $\overline{\mathrm{SE}}$ & Coeff. & SE & Coeff. & $\mathrm{SE}$ & Coeff. & SE \\
\hline Product & QPM & 2.7 & $0.7^{* * * *}$ & 3.2 & $0.6^{* * * *}$ & 3.2 & $0.6^{* * * *}$ & 3.3 & $0.6^{* * * *}$ & 3.0 & 2.0 \\
\hline \multirow[t]{4}{*}{ Design } & Target village & -0.1 & 0.4 & -0.2 & 0.4 & 0.5 & 0.4 & 0.3 & 0.4 & 0.3 & 0.4 \\
\hline & Babati & 0.4 & 0.5 & 1.1 & $0.5^{*}$ & -0.3 & 0.5 & 0.2 & 0.5 & 0.3 & 0.5 \\
\hline & Hai & -0.5 & 0.5 & -0.3 & 0.5 & -0.5 & 0.4 & -0.3 & 0.4 & -0.5 & 0.5 \\
\hline & Presented first & 0.5 & 0.4 & 0.6 & 0.4 & 0.4 & 0.4 & 0.3 & 0.4 & 0.4 & 0.4 \\
\hline \multirow[t]{4}{*}{$\begin{array}{l}\text { Design cross } \\
\text { effects }\end{array}$} & QPM $x$ target village & -0.1 & 0.6 & -0.4 & 0.5 & -0.3 & 0.5 & -0.2 & 0.5 & -0.2 & 0.5 \\
\hline & QPM x Babati & -0.5 & 0.7 & -0.6 & 0.7 & 0.4 & 0.7 & -0.1 & 0.7 & -0.1 & 0.7 \\
\hline & QPM x Hai & 1.4 & $0.7^{*}$ & 1.3 & $0.6^{*}$ & 1.1 & 0.6 & 1.3 & $0.6^{*}$ & 1.2 & 0.7 \\
\hline & QPM x presented first & -0.7 & 0.6 & -1.2 & $0.5^{*}$ & -1.1 & $0.5^{*}$ & -0.9 & 0.5 & -1.1 & $0.6^{*}$ \\
\hline \multirow[t]{3}{*}{ Demographics } & Female & & & & & & & & & 0.3 & 0.4 \\
\hline & Age & & & & & & & & & 0.0 & 0.0 \\
\hline & Education (years) & & & & & & & & & 0.1 & 0.1 \\
\hline \multirow{3}{*}{$\begin{array}{l}\text { Demographic } \\
\text { cross effects }\end{array}$} & QPM $x$ female & & & & & & & & & -0.5 & 0.6 \\
\hline & QPM x age & & & & & & & & & 0.0 & 0.0 \\
\hline & $\begin{array}{l}\text { QPM x education } \\
\text { (years) }\end{array}$ & & & & & & & & & 0.1 & 0.1 \\
\hline \multirow[t]{2}{*}{ Model } & -2 log likelihood & 359.0 & & 422.4 & & 414.6 & & 393.5 & & 387.9 & \\
\hline & $\mathrm{n}$ & 240 & & 240 & & 240 & & 240 & & 240 & \\
\hline
\end{tabular}

${ }^{* * *}=\mathrm{P}<0.001 ;{ }^{* *}=\mathrm{P}<0.01 ;{ }^{*}=\mathrm{P}<0.05$ 


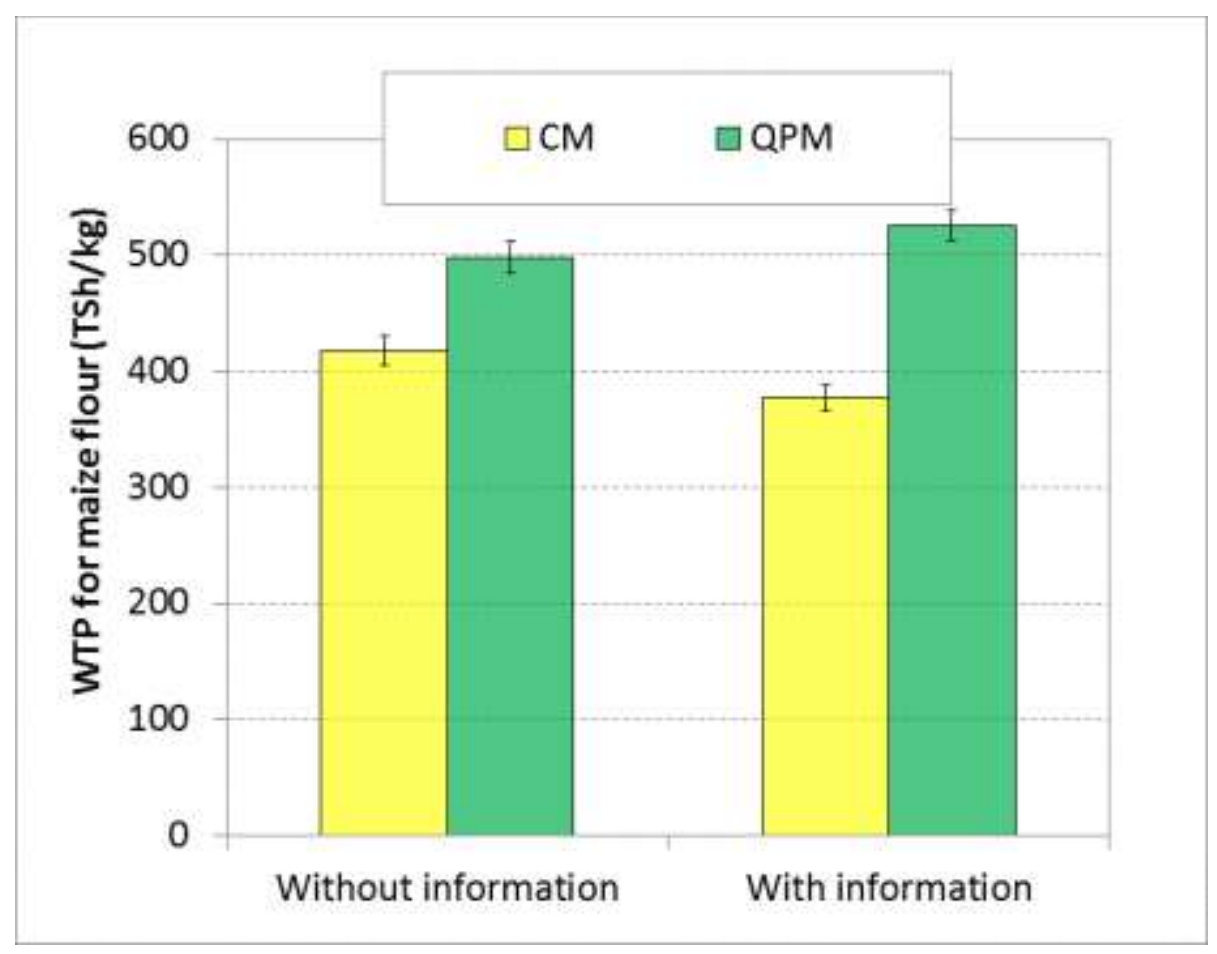

Fig. 5. Willingness to pay for QPM and conventional maize among rural consumers who received information on the nutritional quality of QPM $(n=54)$ and consumers who did not $(n=66)$ (bars are standard errors).

Table 4

Willingness to pay for QPM and conventional maize for rural consumers who received information on QPM $(n=66)$ and consumers who did not $(n=66)$, by district, and outcome of pairwise $t$-test

\begin{tabular}{|c|c|c|c|c|c|c|c|c|c|c|}
\hline \multirow[b]{2}{*}{ District } & \multicolumn{5}{|c|}{ Without information $(n=54)$} & \multicolumn{5}{|c|}{ With information $(n=66)$} \\
\hline & QPM & $\mathrm{CM}$ & $\begin{array}{l}\text { Mean } \\
\text { difference }\end{array}$ & $\begin{array}{l}\text { Premium } \\
(\%)\end{array}$ & & QPM & $\mathrm{CM}$ & $\begin{array}{l}\text { Mean } \\
\text { difference }\end{array}$ & $\begin{array}{l}\text { Premium } \\
(\%)\end{array}$ & \\
\hline \multirow[t]{2}{*}{ Babati } & 485 & 418 & 67 & 16 & ** & 498 & 404 & 94 & 23 & *** \\
\hline & $(108)$ & $(108)$ & $(148)$ & & & (94) & (108) & (121) & & \\
\hline \multirow[t]{2}{*}{ Hai } & 498 & 431 & 81 & 19 & *** & 539 & 377 & 162 & 43 & **** \\
\hline & (94) & (121) & $(108)$ & & & (81) & (94) & $(81)$ & & \\
\hline \multirow[t]{2}{*}{ Karatu } & 512 & 404 & 108 & 27 & **** & 525 & 350 & 175 & 50 & *** \\
\hline & $(81)$ & $(94)$ & (94) & & & (67) & $(108)$ & (94) & & \\
\hline \multirow[t]{2}{*}{ Total } & 498 & 418 & 81 & 19 & **** & 525 & 377 & 148 & 39 & **** \\
\hline & (94) & (108) & (121) & & & (81) & (108) & (108) & & \\
\hline
\end{tabular}

${ }^{* * *}=\mathrm{P}<0.001 ; * *=\mathrm{P}<0.01 ; *=\mathrm{P}<0.05$ 
Table 5

Factors influencing rural consumers' WTP for QPM and CM (linear regression with random effects, N=240)

\begin{tabular}{|c|c|c|c|c|c|c|c|}
\hline \multirow[t]{2}{*}{ Group } & \multirow[t]{2}{*}{ Variable } & \multicolumn{2}{|c|}{$\begin{array}{c}\text { Model } 1 \text { (WTP, } \\
\text { design) }\end{array}$} & \multicolumn{2}{|c|}{$\begin{array}{c}\text { Model } 2 \text { (WTP, } \\
\text { design, } \\
\text { sensory) } \\
\end{array}$} & \multicolumn{2}{|c|}{$\begin{array}{c}\text { Model } 3 \text { (WTP, } \\
\text { design, sensory, } \\
\text { individual) } \\
\end{array}$} \\
\hline & & Coef. & SE & Coef. & $\mathrm{SE}$ & Coef. & SE \\
\hline & Constant & 445.0 & $31.5^{* * * *}$ & 324.7 & $57.8^{* * * *}$ & 264.6 & $89.6^{* *}$ \\
\hline \multirow[t]{2}{*}{ Product } & QPM ugali & 75.9 & $36.8^{*}$ & 14.2 & 85.1 & 13.3 & 108.3 \\
\hline & Consumer acceptance score & & & 34.6 & $14.0^{*}$ & 37.1 & $14.7^{*}$ \\
\hline \multirow[t]{4}{*}{ Design } & Target village & -32.9 & 17.9 & -35.8 & $17.6^{*}$ & -47.5 & $22.2^{*}$ \\
\hline & Information provided & -37.3 & $17.9 *$ & -30.7 & 17.7 & -28.0 & 17.9 \\
\hline & Babati & 39.5 & 23.1 & 36.7 & 22.6 & 39.3 & 23.4 \\
\hline & Hai & 27.7 & 21.4 & 32.1 & 21.1 & 32.3 & 23.9 \\
\hline \multirow[t]{6}{*}{ Individual } & Female & & & & & 18.8 & 18.4 \\
\hline & Age & & & & & 0.8 & 0.9 \\
\hline & Education (years) & & & & & -2.8 & 4.4 \\
\hline & Non-agric. income (1000 TSh) & & & & & 0.0 & 0.0 \\
\hline & Land owned (ha) & & & & & 0.6 & 0.7 \\
\hline & Awareness of QPM & & & & & 9.2 & 23.2 \\
\hline \multirow[t]{2}{*}{ QPM x sens. } & QPM x Sensory evaluation & & & 7.9 & 20.0 & 4.2 & 21.1 \\
\hline & QPM x target village & 25.5 & 20.9 & 26.6 & 19.8 & 35.3 & 25.5 \\
\hline \multirow[t]{3}{*}{ QPM x design } & QPM x information provided & 54.8 & $20.9^{* *}$ & 45.1 & $19.9^{*}$ & 43.6 & $20.4^{*}$ \\
\hline & QPM x Babati & -64.2 & $27.0 *$ & -64.5 & $25.5^{*}$ & -62.6 & $26.7^{*}$ \\
\hline & QPM x Hai & -26.1 & 25.0 & -43.9 & 24.0 & -48.0 & 27.4 \\
\hline \multirow{6}{*}{$\begin{array}{l}\text { QPM x } \\
\text { individual }\end{array}$} & QPM x female & & & & & -23.3 & 21.0 \\
\hline & QPM x age & & & & & 0.4 & 1.0 \\
\hline & QPM x education (years) & & & & & 0.0 & 5.0 \\
\hline & QPM x non-agr. income (1000 TSh) & & & & & -0.4 & 2.1 \\
\hline & QPM x land owned (ha) & & & & & 0.0 & 0.0 \\
\hline & Awareness of QPM & & & & & -9.2 & 26.5 \\
\hline \multirow[t]{7}{*}{ Model } & sigma_u & 54.5 & & 57.8 & & 56.2 & \\
\hline & sigma_e & 80.2 & & 75.8 & & 77.3 & \\
\hline & rho & 0.32 & & 0.37 & & 0.35 & \\
\hline & R-sq within & 0.54 & & 0.60 & & 0.61 & \\
\hline & R-sq between & 0.03 & & 0.04 & & 0.10 & \\
\hline & R-sq overall & 0.30 & & 0.33 & & 0.36 & \\
\hline & Wald chi2(9) & 139.8 & & 174.0 & & 177.2 & \\
\hline
\end{tabular}


Linear regression was used to analyze the effect of these and other factors, in three models with an increasing number of factors (Table 5). The first model contained the design variables but not the evaluation scores, and its results confirm those of Fig. 5 and Table 4. The constant represents the WTP for the base product $(\mathrm{CM})$ without information, in the control villages in the reference district Karatu, and it is estimated at TSh445. The other coefficients are changes in WTP due to the different factors, as compared to this base. The coefficient on QPM is positive and significant at 76, indicating its value is TSh76 higher than that of CM. If information is provided, however, the value of CM is reduced by TSh37 ("Information provided"), while the value of QPM is increased by 55 (“QPM x information provided”). There is also a difference between districts: WTP for QPM is TSh64 less in Babati than in the reference district, Karatu.

When the overall consumer acceptance score is included in the regression, as in the second model, the coefficient on QPM is no longer significant, indicating that the increased WTP for QPM is derived from its sensory evaluation as well as the knowledge about its nutritional value. There is a significant negative effect on the target villages in this model, indicating that WTP for either product is lower in the target villages.

Several consumer characteristics were included in the third model to analyze their possible effect on WTP for both maize types. However, none of these factors, including gender, age, education, and wealth indicators, was found to have a significant effect on WTP for either QPM or CM.

\section{Discussion}

\subsection{Assessing rural consumers' appreciation of new products}

The main objectives of the study were to develop and test a method to assess rural consumers' acceptance and WTP for new maize varieties, and to apply it to evaluate QPM. On the first objective, the major achievement of this research was the development and demonstration of a simplified acceptance elicitation method to assess product acceptance by rural consumers in developing countries, consisting of a modified HUT with the BDM mechanism. This combination offers a powerful and unbiased, yet convenient and cost-effective tool to assess consumers' interest in biofortified crops or other novel products aimed at the rural consumer in 
developing countries. In this new approach the participants are selected randomly from the rural target population, which is different from most CLTs. Moreover, the products are tested in the consumers' familiar environment and the novelty effect is substantially reduced by providing ample time for evaluation. Compared to HUT, the overall study time is much shorter, and the cost much lower.

This powerful tool provides key information needed for product evaluation and dissemination: the modified HUT provides information on consumer acceptance, while the BDM offers an estimate of consumers' WTP, a measure of the product's economic value. In the modified HUT, randomly selected rural consumers individually evaluated the new product prepared in their own homes using their own implements and methods, similar to the classic HUT and in contrast to the CLT, but it was done in a single visit, resulting in a major time and cost reduction compared to the classic HUT, which requires at least three visits. Our experience indicates that for basic and common food preparations, this single visit was sufficient for rural consumers to distinguish two products and express their preferences, which were consistent with those of educated urban consumers doing CLT. The findings were in line with previous research (Meenakshi et al., 2012).

This modified HUT combines well with the BDM procedure, another individual method, which provides important complementary information. The BDM mechanism is based on revealed preference and provides an unbiased WTP estimate (Becker et al., 1964), representing the economic value to the consumer, which can now be evaluated and compared across studies, locations and products. Recent studies used this method with rural consumers with good results, but sufficient time needs to be provided for enumerator training, the method needs to be properly explained to the respondent, and a test round needs to be included (Morawetz et al., 2011). Moreover, adding a short questionnaire allows analysis of factors that affect WTP, in particular consumer acceptance scores, consumers' knowledge of the product (including understanding of relevant health factors for biofortified crops), socioeconomic characteristics such as education and cultural preference, and indicators of vulnerability such as gender, income and wealth. As has been shown before with CLT, information and knowledge affect results (De Groote et al., 2012). The amount of cash provided to participants has also been shown to influence the bids (De Groote, Tomlins, et al., 2010b), but the results indicate that in this study the amount of cash 
provided as well as the random numbers were appropriate: the average bid for conventional maize was below the market price, while that for QPM was around the market price, and overall $57 \%$ of the respondents won the bid.

The combination of these individual methods allows representative sampling of a clearly defined target population to obtain unbiased estimates for that population, which is particularly interesting when the target group is rural households, as it is for biofortified crops. In contrast, most group methods, including CLT and group auctions, rely on volunteers or convenience samples (Demont et al., 2012), which might not be representative of the target population. Our experience showed the convenience of the method: it is fairly easy to conduct and requires only one visit to the homestead. Its components, particularly tasting a new product and playing a game with real money but no risk, are entertaining for the participant as well as the enumerator. The good working environment is conducive to concentration, which leads to better quality results.

The combination of CLT and group auctions is still an appropriate alternative where households are concentrated in villages, and the random selection of target individuals can be done with limited transport costs (De Groote et al., 2012). Group methods also have their use in combination with the method proposed here. We particularly found it useful to conduct a CLT with a triangle test first: the triangle test was a simple and effective way to determine whether consumers can distinguish between products and, combined with CLT, to identify the criteria that drive the distinction. It also offered an opportunity for the enumerators to test the procedures and provided a first approximate indicator of consumer acceptance of the new product.

The preliminary central location test took only one day to evaluate the products for a wide range of characteristics on the 9-point scale. It made the triangle test possible, which would be difficult in home-use testing, and offered good training for the enumerators. For the staff of the research institute, educated people with exposure to the principles of research, the 9-point scale did not pose any difficulties. For rural consumers, the 5-point Likert scale was easy and convenient, applicable in any language, and provided sufficient power to detect existing differences in appreciation. However, the consumers did not use the lowest score, and few the 
2nd lowest score, but they did use the highest, especially for QPM. A sufficient sample size or large enough effect size can overcome this limitation, as it did in this study.

The results do not, however, allow for a definitive comparison of CLT and HUT because they are confounded by the location: the CLT was conducted in a peri-urban area while HUT was conducted in rural areas. In both tests, consumers expressed preference for the QPM variety, and the confounding effect would be expressed in the magnitude of the difference in preferences.However, results in nearby countries suggest that acceptability of QPM does not differ among urban and rural consumers (observed in Kenya) or consumers of varying education (observed in Ethiopia as well as this study) (De Groote et al., forthcoming). Therefore, location is probably not a major confounder.

\subsection{Assessing rural consumers' appreciation of $Q P M$}

On the second objective, applying the method to QPM, the results show clearly that rural consumers in Tanzania could distinguish QPM from conventional maize in ugali and preferred the QPM ugali, as expressed by higher scores during sensory evaluation in both the CLT and modified HUT for all criteria except appearance. This preference occurred in all districts, although with some difference between them, which could not be linked to any observed socioeconomic or cultural differences.

Moreover, during experimental auctions after sensory evaluation, rural consumers were willing to pay $16 \%$ more for QPM flour than for CM flour, even without receiving any information about QPM's nutritional benefits. Consumers who received such information were willing to pay $39 \%$ more. In the regression on WTP, when sensory evaluation and information is included, the coefficient on QPM is no longer significant, indicating that appreciation of sensory characteristics and information were the main drivers of WTP.

The premium by consumers who received the information was partly an increase in WTP for QPM, but the larger part came from a decrease in WTP for conventional maize. This might be explained by the negative information provided on conventional maize contrasted with QPM, in 
particular its poor protein quality and shortage of essential amino acids. Future studies might want to try to avoid this, but it would be hard to explain the benefit of a biofortified crop without explaining the deficiencies of the conventional varieties. A similar negative effect of information on WTP for the conventional varieties was found during an experiment with rural consumers in Ghana with orange maize, biofortified with provitamin A carotenoids (De Groote, Tomlins, et al., 2010b), In Ghana, the message contained positive information on the benefits of vitamin A and biofortified maize, but no explicit negative information about the lack of it in conventional varieties. Still, labels on new products with positive messages to distinguish them can simultaneously stigmatize the conventionally produced product by highlighting perceived problems, and thereby reducing WTP for the conventional product.An experiment in the US identified this stigma for milk, where the introduction of growth-hormone free and organic milk labels reduced consumers' WTP for conventional milk by $33 \%$ and 45\%, respectively (Kanter, Messer, \& Kaiser, 2009). Similarly, another experiment conducted in France showed a reduction in WTP for conventional food products after the introduction of certified products (for heavy metal content), and no increase in WTP for the latter (Rozan, Stenger, \& Willinger, 2004). An alternative explanation is that participants link the bids, as through imaginary budget constraints.

The QPM variety tested, Lishe K1, had better sensory characteristics than its conventional counterpart, which should help the promotion and dissemination of this variety. However, previous research and informal discussions indicate that consumers do not appreciate the small grain size of this particular variety, and adoption has been limited (De Groote et al., 2009). In fact, except for Obatampa in Ghana and its derivative, Longe 5, in Uganda, no QPM varieties have been popular in Africa. Therefore, other important variety characteristics need to be evaluated, in particular field characteristics such as yield and maturity time, as well as postharvest qualities such as resistance to storage pests, should also be evaluated. Further, to analyze whether the main factors in the positive evaluation of Lishe K1 are linked to the QPM trait or to other traits specific to the varieties tested, the consumer acceptance study should be repeated with other QPM varieties available in the country, preferably with comparison of near-isogenic varieties.

In a more general perspective, the results indicate that traits like quality protein, that are not visible or otherwise apparent to producers, can still change sensory characteristics. Therefore, it 
is important to conduct sensory evaluation and consumer acceptance studies with the biofortified varieties currently under development. Our results show that regional differences can occur, concurring with the Ghana study on provitamin A biofortified maize, where the differences were much larger. This emphasizes the need for a representative sample of the target population (rural consumers) for biofortified varieties. The method developed here should be applicable to most of these varieties and preparations. For fermented products, common in West Africa, multiple visits might be necessary. Further, the experimental economics part adds an important dimension, since it measures a wider appreciation than just the sensory; it uses a money metric so it allows for a wider interpretation, and it allows the measurement of the effect of information. As shown in this study, the BDM method is useful and feasible with a dispersed population of rural consumers. Finally, our study, in line with the Ghana and Zambia studies (Meenakshi et al., 2012) shows that providing information on the nutritional benefits of biofortified crops increases consumer acceptance and WTP. However, the effect of the short information message that can be transferred during an experiment of this nature is likely quite different from that of substantial information campaigns through mass communication media, agricultural extension and health services. Therefore, research on the effect of these campaigns, and their content and design, is needed to bring these varieties to their end users.

\section{Conclusion}

From the experience with this newly-developed method, we conclude that the combination of the modified HUT and BDM is particularly suited to assess the acceptance of novel products targeted at rural consumers in developing countries, such as biofortified crops. The method is convenient and cost effective, and can be conducted over a large geographical area. Moreover, it informs both development and dissemination efforts. It provides feedback to product development by providing accurate information on the level of acceptance of the product by target consumers, as well as their WTP for it. Finally, it helps to develop efficient dissemination strategies by identifying the knowledge factors (awareness of the product, understanding of its benefits) that can tip the balance towards acceptance, adoption and, ultimately, improvement in health and nutrition of the target population. 
From the results, we conclude that sensory characteristics of the tested QPM variety, Lishe K1, like those tested in other countries, are generally positive and do not pose a hindrance to its dissemination and adoption. Still, the variety is not widely adopted, and neither are other QPM varieties except for Obatampa in Ghana and Longe 5, in Uganda. Clearly, these varieties are not the most preferred in today's highly competitive maize seed sector. While information campaigns can help, more effort is needed to make QPM varieties competitive with their conventional counterparts, and engage the private sector in their dissemination.

\section{Acknowledgements}

The authors would like to thank the Canadian International Development Agency (CIDA) for funding this research through the Quality Protein Maize Development (QPMD) project, the project leader, Dennis Friesen, for his support and encouragement, Simon Kimenju for his help with setting up the study, and Kathleen Sinclair for editing the manuscript. We appreciate the collaboration with the staff of the Selian Agricultural Research Institute in Arusha, Tanzania, and the enumerators, and thank the participants in this study for their time and effort.

\section{References}

Ahenkora, K., S., Twumasi-Afriyie, S. P. Y. K., \& Obeng-Antwi, K. (1999). Protein nutritional quality and consumer acceptability of tropical Ghanaian quality protein maize. Food and Nutrition Bulletin, 20, 354-360.

Atlin, G. N., Palacios, N., Babu, R., Twumasi-Afriye, S., De Groote, H., Vivek, B., et al. (2010). Quality Protein Maize: progress, impact, and prospects. Plant Breeding Reviews, 34, 83-130.

Banerji, A., Chowdhury, S., De Groote, H., Meenakshi, J. V., Haleegoah, J., \& Ewool, M. (2013). Using Elicitation Mechanisms to Estimate the Demand for Nutritious Maize: Evidence from Experiments in Rural Ghana. HarvestPlus Working Paper No. 10.

Becker, G. M., DeGroot, M. H., \& Marschak, J. (1964). Measuring utility by a singleresponse sequential method. Behavioral Science, 9(3), 207-299. 
Bellon, M. R., Adato, M., Becerril, J., \& Mindek, D. (2006). Poor farmers' perceived benefits from different types of maize germplasm: The case of creolization in lowland tropical Mexico. World Development, 34(1), 113-129.

Bennett, J., \& Birol, E. (2010). Choice Experiments In Developing Countries. Implementation, Challenges and Policy Implications. In. Cheltenham Glos, UK: Edward Elgar Pub.

Bouis, H. E. (1996). Enrichment of food staples through plant breeding: a new strategy for fighting micronutrient malnutrition. Nutr Rev, 54, 131-137.

Bouis, H. E. (1999). Economics of enhanced micronutrient density in food staples. Field Crops Research, 60(1-2), 165-173.

Boutrolle, I., Arranz, D., Rogeaux, M., \& Delarue, J. (2005). Comparing central location test and home use test results: Application of a new criterion. Food Quality and Preference, 16(8), 704-713.

Boutrolle, I., Delarue, J., Arranz, D., Rogeaux, M., \& Köster, E. P. (2007). Central location test vs. home use test: Contrasting results depending on product type. Food Quality and Preference, 18(3), 490-499.

Campos-Bowers, M. H., \& Wittenmyer, B. F. (2007). Biofortification in China: policy and practice. Health Research Policy and Systems, 5(10), 1-7.

Chowdhury, S., Meenakshi, J. V., Tomlins, K., \& Owori, C. (2011). Are consumers willing to pay more for biofortified foods? Evidence from a field experiment in Uganda. American Journal of Agricultural Economics, 93, 83-97.

Coe, R. (2002). Analyzing ranking and rating data from participatory on-farm trials. In M. R. Bellon \& J. Reeves, Quantitative analysis of data from participatory methods in plant breeding. Mexico, DF.: CIMMYT.

Dankyi, A. A., Sallah, P. Y. K., Adu-Appiah, A., \& Gyamera-Antwi. (2005). Determinants of the Adoption of Quality Protein Maize, Obatanpa, in Southern Ghana - Logistic Regression Analysis. In: Paper Presented At The Fifth West And Central Africa Biennial Regional Maize Workshop, 2 - 6 May 2005, lita-Cotonou, Republic Of Benin.

De Groote , H., Gunaratna, N. S., Kebebe, E., Lyimo, S. D., Ouma, J. O., Kyazze, F. B., et al. (2009). Indicators of QPMD project performance: A survey of potential impact on QPM on nutrition, health and wellbeing of farm households and the impact of the QPMD project on QPM awareness and adoption in target areas in Ethiopia, Kenya, Tanzania and Uganda-project report prepared for the Canadian International Development Agency (CIDA). June 2009. In. Nairobi, Kenya. : CIMMYT.

De Groote, H., Gunaratna, N. S., Okuro, J. O., Wondimu, A., Chege, C. K., \& Tomlins, K. (forthcoming). Consumer acceptance of quality protein maize (QPM) in East Africa. Journal of the Science of Food and Agriculture.

De Groote, H., Gunaratna, N. S., Ouma, J. O., Wondimu, A., Kiria, C. G., \& Tomlins, K. (2014 (forthcoming)). Consumer acceptance of Quality Protein Maize in East Africa. Journal of the Science of Food and Agriculture.

De Groote, H., \& Kimenju, S. C. (2008). Comparing consumer preferences for color and nutritional quality in maize: Application of a semi-double-bound logistic model on urban consumers in Kenya. Food Policy, 33(4), 362-370. 
De Groote, H., Kimenju, S. C., \& Morawetz, U. B. (2011). Estimating consumer willingness to pay for food quality with experimental auctions: the case of yellow versus fortified maize meal in Kenya. Agricultural Economics, 42(1), 1-16.

De Groote, H., Narrod, C., Bett, S. K. C., Scott, R., \& Tiongco, M. (2011). Measuring rural consumers' willingness to pay for quality labels using experimental auctions: the case of aflatoxin free maize in Kenya. Poster paper presented at the European Association of Agricultural Economics Congress 2011, Zurich, Switzerland, August 30th to September 2nd, 2011.

De Groote, H., Rutto, E., Odhiambo, G., Kanampiu, F., Khan, Z., Coe, R., et al. (2010). Participatory evaluation of integrated pest and soil fertility management options using ordered categorical data analysis. Agricultural Systems, 103, 233-244.

De Groote, H., Tomlins, K., Haleegoah, J., Awool, M., Frimpong, B. N., Banerji, A., et al. (2010a). Assessing rural consumers' WTP for orange, biofortified maize in Ghana with experimental auctions and a simulated radio message. Paper presented at the African Agricultural Economics Association Conference - Cape Town, 19-23 September 2010. In.

De Groote, H., Tomlins, K., Haleegoah, J., Awool, M., Frimpong, B. N., Banerji, A., et al. (2010b). Assessing rural consumers' WTP for orange, biofortified maize in Ghana with experimental auctions and a simulated radio message. Paper presented at the Conference of the African Agricultural Economics Association, Cape Town, South Africa, 19th - 23rd September 2010.

De Groote, H., Tomlins, K., Meenakshi, V. S., Kiria, C., Morawetze, U., \& Gunaratna, N. (2012). Experimental methods to analyze the preferences of rural consumers in developing countries. Paper presented at the Twenty-eighth International Conference of Agricultural Economists (ICAE), Foz do Iguaçu, 18-24 August 2012. In.

Demont, M., Zossou, E. r., Rutsaert, P., Ndour, M., Van Mele, P., \& Verbeke, W. (2012). Consumer valuation of improved rice parboiling technologies in Benin. Food Quality and Preference, 23(1), 63-70.

Food and Agriculture Organization. (2009). Food balance sheet. . In. Rome.[Online] Available from http://faostat.fao.org/site/368/default.aspx\#ancor [Accessed: 2010-01-06]. FAO. .

Ghosh, S., Suri, D., \& Uauy, R. (2012). Assessment of protein adequacy in developing countries: Quality matters. British Journal of Nutrition, 108, S77-S87.

Green, W. H. (2008). Econometric analysis. USA: Prentice Hall.

Greene, W. H. (1991). Econometric Analysis. New York: Mcmillan Publishing Company.

Griffin, R., \& Stauffer, L. (1990). Product optimization in central-location testing and subsequent validation and calibration in home-use testing. Journal of Sensory Studies, 5(4), 231-240.

Gunaratna, N. S., De Groote , H., Nestel, P., Pixley, K. V., \& McCabe, G. P. (2010). A Meta-analysis of Community-level Studies on Quality Protein Maize. Food Policy, 35, 202-210.

Haas, J. D., Beard, J. L., Murray-Kolb, L. E., Mundo, A. M. d., Felix, A., \& Gregorio, G. B. (2005). Iron-Biofortified Rice Improves the Iron Stores of Nonanemic Filipino Women. The Journal of Nutrition., 135, 2823-2830. 
Johns, T., \& Eyzaguirre, P. B. (2007). Biofortification, biodiversity and diet: A search for complementary applications against poverty and malnutrition. Food Policy, 32, 124.

Kanter, C., Messer, K. D., \& Kaiser, H. M. (2009). Does Production Labeling Stigmatize Conventional Milk? American Journal of Agricultural Economics, 91(4), 10971109.

Kimenju, S. C., \& De Groote, H. (2008). Consumers' willingness to pay for genetically modified food in Kenya. Agricultural Economics, 38(1), 35-46.

Krivanek, A. F., De Groote, H., Gunaratna, N. S., Diallo, A. O., \& Friesen, D. (2007). Breeding and Disseminating Quality Protein Maize (QPM) for Africa. African Journal of Biotechnology, 6(4), 312-324.

Lancaster, K. J. (1966). A New Approach to Consumer Theory. Journal of Political Economy, 74(2), 132-157.

Low, J. W., Arimond, M., Osman, N., Cunguara, B., Zano, F., \& Tschirley, D. (2007). A Food-Based Approach Introducing Orange-Fleshed Sweet Potatoes Increased Vitamin A Intake and Serum Retinol Concentrations in Young Children in Rural Mozambique. Journal of Nutrition, 137(5), 1320-1327.

Lusk, J. L., Feldkamp, T., \& Schroeder, T. C. (2004). Experimental Auction Procedure: Impact on Valuation of Quality Differentiated Goods. American Journal of Agricultural Economics, 86(2), 389-405.

Maddala, G. S. (1983). Limited-dependent and qualitative variables in econometrics. New York: Cambridge University Press.

Martins, J. L., Jideani, I. A., Yusuf, I. Z., \& Tahir, F. (2010). Comparative consumer acceptability and food utilization analysis of three maize varieties. Nutrition \& Food Sciences, 40(3), 323-329.

McCullagh, P. (1980). Regression Models for Ordinal Data. Journal of the Royal Statistical Society. Series B (Methodological), 42, 109-142.

McCulloch C.E., Searle S.R., \& J.M, N. (2008). Generalized, Linear, and Mixed Models: Second Edition John Wiley and Sons, Inc, Hoboken, NJ, USA.

Meenakshi, J. V., Banerji, A., Manyong, V., Tomlins, K., Hamukwala, P., Zulu, R., et al. (2010). Consumer acceptance of provitamin A orange maize in rural Zambia: HarvestPlus working paper No.4. In. Washington, DC,USA: HarvestPlus

Meenakshi, J. V., Banerji, A., Manyong, V., Tomlins, K., Mittal, N., \& Hamukwala, P. (2012). Using a discrete choice experiment to elicit the demand for a nutritious food: Willingness-to-pay for orange maize in rural Zambia. Journal of Health Economics, 31(1), 62-71.

Meenakshi, J. V., Johnson, N. L., Manyong, V. M., DeGroote, H., Javelosa, J., Yanggen, D. R., et al. (2010). How Cost-Effective is Biofortification in Combating Micronutrient Malnutrition? An Ex ante Assessment. World Development, 38(1), 64-75.

Meilgaard, M., Civile, G. V., \& Carr, B. T. (2007). Sensory Evaluation Techniques 4th Edition. Florida, USA: CRC Press.

Ministry of Agriculture and Cooperatives. (2001). Basic Data, Agriculture and Livestock Sector, 1992/93 - 1998/99:Tanzania mainland. In. Dar Es Salaam.: Republic of Tanzania. 
Morawetz, U. B., De Groote, H., \& Kimenju, S. C. (2011). Improving the Implementation of Experimental Auctions in Africa: Theory and Evidence. Journal of Agricultural and Resource Economics, 36(2), 263-279.

Moshi, A. (1997). Economic impact of maize research in Tanzania. Gaborone, Botswana: Southern African Center for Cooperation in Agricultural and Natural Resources Research \& Training.

Naico, A. T., \& Lusk, J. L. (2010). The value of a nutritionally enhanced staple crop: results from a choice experiment conducted with orange-fleshed sweet potatoes in Mozambique. Journal of African Economies, 19(4), 536-558.

Pardo, T. F., Mora, J. O., Paez, Y., De Orstruss, J., \& De la Cruz-Villata, M. (1972). Acceptabilidad del maiz opaque-2 en Colombia. Arch Latinam Nutr Rev, 22, 561575.

Pellett, P. L. (1996). World essential amino acid supply with special attention to SouthEast Asia. Food and Nutrition Bulletin, 17(3), 204-234.

Pellett, P. L., \& Ghosh, S. (2004). Lysine Fortification: Past, Present, and Future. Food and Nutrition Bulletin, 25, 107-113.

Rozan, A., Stenger, A., \& Willinger, M. (2004). Willingness-to-pay for food safety: an experimental investigation of quality certification on bidding behaviour. European Review of Agricultural Economics, 31(4), 409-425.

Rutsaert, P., Demont, M., Ndourb, M., \& Tollens, E. (2009). Competitive Rivals: Willingness-to-pay for Senegal River Valley versus Imported Rice. In, Workshop on Valuation Methods in Agro-food and Environmental Economics: "Experimental Auctions: Theoretical Background and Empirical Applications". Barcelona.

Shogren, J. F. (2005). Experimental methods and valuation. Chapter 19. In L.-G. Mäler, J. R. Vincent \& B. V. A. r. reserved, Handbook of Environmental Economics, Volume 2: Elsevier.

Stevens, R., \& Winter-Nelson, A. (2008). Consumer acceptance of provitamin Abiofortified maize in Maputo, Mozambique. Food Policy, 33(4), 341-351.

Stevens, S. S. (1946). On the Theory of Scales of Measurement. Science, 103(2684), 677-680.

Tomlins, K., Manful, J., Gayin, J., Kudjawu, B., \& Tamakloe, I. (2007). Study of sensory evaluation, consumer acceptability, affordability and market price of rice. Journal of the Science of Food and Agriculture, 87(8), 1564-1575.

Tomlins, K., Rwiza, E., Nyango, A., Amour, R., Ngendello, T., Kapinga, R., et al. (2004). The use of sensory evaluation and consumer preference for the selection of sweetpotato cultivars in East Africa. Journal of the Science of Food and Agriculture, 84, 791-799

Tomlins, K., Sanni, L., Oyewole, O., Dipeolu, A., Ayinde, I., Adebayo, K., et al. (2007). Consumer acceptability and sensory evaluation of a fermented cassava product (Nigerian fufu). Journal of the Science of Food and Agriculture, 87(10), 19491956.

Tomlins, K. I., Manful, J. T., Larwer, P., \& Hammond, L. (2005). Urban consumer preferences and sensory evaluation of locally produced and imported rice in West Africa. Food Quality and Preference, 16(1), 79-89.

Train, K. E. (2003). Discrete Choice Methods with Simulation: Cambridge University Press. 
van Jaarsveld, P. J., Faber, M., Tanumihardjo, S. A., Nestel, P., Lombard, C. J., \& Spinnler Benadé, A. J. (2005). $\beta$-carotene-rich orange-fleshed sweet potato improves the vitamin A status of primary school children assessed with the modified-relative-dose-response test. American Journal of Clinical Nutrition, 81, $1080-1087$.

Vasal, S. K. (2000). The quality protein maize story. Food and Nutrition Bulletin, 21, 445-450.

Watts, B. M., Ylimaki, G. L., Jeffery, L. E., \& Elias, L. G. (1989). Basic sensory methods for food evaluation. Ottawa, Ontario: International Development Research Centre.

Young, V. R., \& Pellett, P. L. (1990). Current concepts concerning indispensable amino acid needs in adults and their implications for international nutrition planning. Food and Nutrition Bulletin, 12(4), 289-300. 


\section{Appendix 1. English-Swahili translation of terms used}

\begin{tabular}{lll}
\hline Class & English & Swahili \\
\hline Score & Very bad & Bayasana \\
& Bad & Baya \\
& Fair & Kadri \\
& Good & Zuri \\
& Very good & Zurisana \\
\hline Criteria & Taste & Ladhayaugali \\
& Texture in the hand & Chembechembeza ugali mkononi \\
& Texture in the mouth & Chembechembeza ugali mdomoni \\
& Overall & Kwa ujumla \\
\hline
\end{tabular}




\section{Appendix 2. Information provided on quality protein maize (QPM)}

(This is the English translation of the text which was actually read to the respondents in Kiswahili)

Quality protein maize (QPM) areimproved maize varieties that were bred for higher lysine and tryptophan levels. QPM is not genetically modified; it is a product of conventional breeding.

The protein of conventional maize is not high quality because it lacks the full range of amino acids (in particular lysine and tryptophan), which are needed to produce proteins. Without additional protein sources, only $40 \%$ of the protein can be used by humans. This makes conventional maize a poor-quality food staple, unless it is consumed as part of a varied diet that includes complementary protein sources, in particular animal source foods or legumes (such as beans), which are more expensive.

Proteins are very important: they constitute about $25 \%$ of the body weight of adults and they are the building blocks of the body. A chronic lack of protein in the diet leads to kwashiorkor. Maize-based diets high in conventional maize without complementary protein sources can cause protein deficiency. Babies weaned on a diet based on conventional maize alone are frequently underweight and prone to disease.

QPM contains nearly twice as much usable protein as the conventional maize in a pure maize diet because it produces 70\%-100\% more lysine and tryptophan than conventional maize varieties. These two amino acids allow the body to manufacture complete proteins, thereby reducing the risk of kwashiorkor.Babies and adults consuming QPM are healthier and are at a lower risk of malnutrition disorders such as kwashiorkor.

Monogastric animals (e.g., pigs, chicken, etc.) fed on QPM experience faster weight gain and are ready for market sooner or can provide an additional quality protein source for small farm families. 